\title{
Insurgence and National Security in Nigeria: A Focus on Boko Haram
}

\author{
Able Shibinya Zhizhi ${ }^{1} \&$ Emmanuel Okokondem Okon $^{2}$ \\ ${ }^{1}$ Department of Politcal Science, Nasarawa State University, Keffi, Nigeria \\ ${ }^{2}$ Department of Economics, Kogi State University, Anyigba, Kogi State, Nigeria \\ Correspondence:Emmanuel Okokondem Okon, Department of Economics, Kogi State University, Anyigba, Kogi \\ State, Nigeria, E-mail: tonydom57@yahoo.com. Tel: +2348023275716
}

Received: January 6, 2018

Accepted: January 9, 2018

Online Published: January 18, 2018

\begin{abstract}
The contemporary Nigeria has become a theatre of genocide, bloodshed and insecurity over the past years due to the carnage activities of terrorist groups. Terrorists of various groups and camps unleash havoc on the Nigerian populace. Though these groups are numerous, one of the most noticeable and deadly group is Boko Haram. This paper attempts to investigate if this group is one of the major security challenges confronting Nigeria today. The result reveals that a number of factors, including bad governance and religious and political manipulations, and the long and porous borders of Nigeria promote Boko Haram activities. As such, there is significant relationship between Boko Haram insurgency and national security in Nigeria. This paper recommends that at all levels of government, governance should be taken as a serious business especially in the area of provision of security and public goods such as improved infrastructure and the creation of the enabling environment needed for investment that would in turn creation opportunities for employments which will lead to reduction in poverty.
\end{abstract}

Keywords: Insurgence, National Security, Boko Haram, Nigeria.

\section{Introduction}

For most people, the history of Nigeria is that of violent conflicts, chaos, and disorderliness, and retrogression. Some people have become inured to the ugly and obscene pictures of the maimed, charred human bodies, and the wanton destruction of properties as a result of some of the violence reminiscence of the Nigeria civil war. It is possible for anyone to develop amnesia over these horrible violent incidents that have occurred over some decades. And many people cannot live down the orgy of violence resulting to the savage carnage and horror. The overall consequence is that the collective psyche of the people has been affected (Udama, 2013).

Terrorism though not new in Nigeria history, but has become the popular vehicle for instilling fear and conducting violence against the citizens in the country. In recent times, Nigeria is experiencing a new wave of violence which is terrorism conducted in different forms, means and places. These includes bombing and killing of persons and targeting certain persons and places such as worship centre's, living homes, commercial buildings, telecommunication masts, government installations and infrastructure, kidnapping as well as depriving people of their legitimate entitlements (Udama, 2013). These terrorist activities are carried out by non-state actors and do not exclude politicians and government functionaries including security agencies that ought to protect lives and properties.

Since 2001, a new crop of young and daring Muslim faithful known as Boko Haram, where most of them are from the semi-middle class and educated have aggressively embraced a stricter version of Islam, rejecting anything Christian and western education and culture, have had undiluted resilience carrying high profile terrorist attacks particularly in the northern states of Borno, Yobe, Adamawa, Bauchi, Gombe, Plateau, Kaduna, as well as the 
Federal Capital Territory (FCT) (Udama, 2013). They also have freed suspects from prisons, killing high profile politicians, and carried out the first suicide bomb attack in the Abuja police force Headquarters. This has prompted the question of who will protect the Nigerian citizens, if the forces saddled with the responsibility are helpless.

This paper seeks to answer the following research questions whether a number of factors, including illiteracy, unemployment and poverty, corruption, bad governance and religious and political manipulation, and the long and porous borders of Nigeria, its vast forest and deserts most of which are not adequately protected, as well as weak institutional frameworks, constitute weaknesses that promote Boko Haram activities. The basic research proposition of this paper is that there is no significant relationship between Boko Haram insurgency and national security in Nigeria.

\section{Conceptual Review}

2.1 National Security

The term national security lacks specific definition. This is partly because the nature and concept of national security may vary from one State to the other. Meanwhile, security refers to the effort to protect the lives and properties of people from threats. It is the state of being secure; freedom from fear, anxiety, danger, and doubt. The threats that people are being protected from via security can take several forms, and could be from anywhere, they could be internal, external, visible, and perceived. Accordingly, in order to possess national security, a nation needs to possess economic security, energy security, environmental security, etc(Sciencedaily, 2015). Security threats involve not only conventional foes such as other nation-states but also non-state actors such as violent non-state actors, narcotic cartels, multinational corporations and non-governmental organizations; some authorities include natural disasters and events causing severe environmental damage in this category.

Generally, Braithwaite (1988) quoting the encyclopedia of the social sciences defines national security as "ability of a nation to protect its internal values from external threat". Also, Lipmann defines it by stating that "a nation has security when it does not have to sacrifice its legitimate interest to avoid war, and is able, if challenged, to maintain them by war". Morgenthau (1948) posits that national security and national interests are inter-related; where the former is seen in terms of power and therefore is the essence of politics. Imobighe (1981) refers to it as the defense and survival of the state. The danger of looking at national security from this narrow angle according to Nweke (1988) is three-fold; but we shall concern ourselves with the first two: First is the tendency to equate "defense" with "security" and to bestow undue responsibilities to the military as if the armed forces alone are the guardians of national security. This tendency in turn creates in the minds of the armed forces that it is only through them that security, stability and progress can be achieved. Secondly, national security has been used by civilian statesmen as political rhetorics or slogan for rallying the citizens in the face of perceived internal or external threats to the governments in power and for bolstering their local influence and political base (Adebayo, 1986).

Dyke (1966), concludes that there is no doubt that national security embodies the sovereignty of the state, the inviolability of its territorial boundaries, and the right to individual and collective self-defense against internal and external threats. But the state is secure only when the aggregate of people organized under it has a consciousness of belonging to a common sovereign political community; enjoy equal political freedom, human rights, economic opportunities, and when the state itself is able to ensure independence in its development and foreign policy.

Freedman's (1998) view is that once anything generates anxiety or threatens the quality of life in some respect, it is thus labeled a "security problem". The notion of economic security thus encourages a confrontational approach to trace policy, while that of "environmental security" has often served more to confuse than to clarify by encouraging a search for adversaries. National security according to Otubanjo (1989) is the concern of government about the stability and safety of a state. Similarly, Adesola (2011) explains national security as the measures taken by a state to ensure its survival and safety. In the Nigerian context, Edem (n.d.) defines national security as the ability of Nigeria to pursue her national interest and protect her core values. The thrust of this state centred definition is to view national security in terms of defence and survival of the State. In this context, "defence" is equated with "security" and the military as the custodians of national security (Oshio, 2009). Furthermore, Otto and Ukpere (2012, p.6767) asserts that "security means protection from hidden and hurtful disruptions in the patterns of daily life in homes, offices or communities... security must be related to the presence of peace, safety, happiness and the protection of human and physical resources or the absence of crisis, threats to human injury among others."

There is a remarkable difference between what the concept of national security is in contemporary and traditional periods. National security was traditionally viewed as referring to the protection of the territorial integrity of a state and the protection of its citizens from external threats, with specific focus on protection against military attack. This concept has been described as an evolving one which changed and became seen as not only covering protection of a state's territory from external threats, but to also cover internal threats including unrests, as well as enhancing the lives of the of the people in the state, and the provision of infrastructure needed for development. 
The concept has in contemporary times gone beyond those two to include protection not just from internal and external threat, but also to threats to a state's way of life. The present scope of the threats that states seek to protect themselves from goes beyond military threats, unrests and other upheavals, to include other forms of threats such as economic, health, social or political. Therefore, the modern understanding of national security however extends beyond the physical protection of a territory through military intervention, to the provision of better quality of life and promotion of sustainable development. In this light, national security can be described to include providing higher standard of living through health, economic, human, physical and environmental and food security among others (Bello, n.d.).

2.2 Insurgency

Scholars and theorists have given different definitions of insurgency. While some of these definitions are closely related, others are not so related though contain common elements and this still makes the subject technically difficult. Perhaps insurgency is best understood by first considering what it is not. Insurgency is not terrorism or conventional war for example, though it shares with them some similarities such as the use of force or guerrilla tactics to achieve an end which is often political (Liolio, 2013). Basically, the difference between insurgency and terrorism lies in the scope and magnitude of violence. While for instance, terrorism rarely brings about political change on its own, insurgency attempts to bring about change through force of arms. Similarly, terrorists often apply a wide range of damages when compared to insurgents. On the other hand, while conventional war involves adversaries more or less symmetric in equipment or training, insurgency involves adversaries that are asymmetric, weak, and almost always a sub-state group.

Traditionally however, insurgencies seek to overthrow an existing order with one that is commensurate with their political, economic, ideological or religious goals (Gompert and Gordon, 2008). According to Kilcullen, "Insurgency is a struggle to control a contested political space, between a state (or a group of states or occupying powers), and one or more popularly based, non-state challengers" (Kilcullen 2006). Kilcullen also try to draw a line between classical and contemporary insurgencies thus: while the latter seek to replace the existing order, the former sometimes strive for the expulsion of foreign invaders from their territory or seek to fill an existing power vacuum (Kilcullen 2006). Similarly, the Oxford English Dictionary defines insurgency as "an armed rebellion against a constituted authority (for example, an authority recognized as such by the United Nations) when those taking part in the rebellion are not recognized as belligerents."

The British Army counter-insurgency manual, Army Field Manual (AFM) defined insurgency as: "The actions of a minority group within a state, who are intent on forcing political change by a means of a mixture of subversion, propaganda and military pressure, aiming to persuade or intimidate the broad mass of the people to accept such a change. It is an organized, armed political struggle, the goals of which might be diverse."

This definition also conform with the US Army-Marine Corps Counterinsurgency Field Manual (FM 3-24) which defined insurgency as "an organized, protracted politico-military struggle designed to weaken the control and legitimacy of an established government, occupying power, or other political authority while increasing insurgent control"(Petraeus and Amos 2006).

Apart from the definition by Kilcullen and to an extent that of Oxford dictionary, the author does not totally agree with the other definitions as they fail to reflect the complexities of modern insurgencies especially with regards to their political, economic and social dimensions which Kilcullen simply describe as "struggle." By implication, the other definitions branded insurgency as a predominantly military problem. However, in what seems to be a replacement of the 2006 FM 3-24 definition of insurgency, the 2009 Joint Publication 3-24 Counterinsurgency Operations, defined insurgency as "the organized use of subversion and violence by a group or movement that seeks to overthrow or force change of a governing authority." While the author agrees more with this definition by the Joint Publication, he wishes to stress that such definition excludes any insurgency that does not seek to overthrow or change the governing authority. A good example would be separatist insurgencies which aim for secession from within a state or reformist insurgencies which seek to influence government policies by forceful means.

In all, insurgencies connote an internal uprising often outside the confines of state's laws and it is often characterized by social-economic and political goals as well as military or guerrilla tactics. Put differently, it is a protracted struggle carefully and methodically carried out to achieve certain goals with an eventual aim of replacing the existing power structure. To launch their anger on the state, insurgents often target civilians and infrastructures. However, other than the violence of insurgency are its political and social-economic dimension, where often lies its causes and effects.

\section{Insecurity in Nigeria}

The myriad of security problems confronting Nigeria have had dire impact on the socio-economic and political development in the country. Odeselu (2011), confirms that insecurity in Nigeria has affected Air transport negatively. It scares away passengers and is like draining blood from a man, it drains the resources that could have 
been used to improve safety, including finance and time. It induces multiple levels of security checks at the airports with the attendant stress on the traveling public. Otto (2008) has shown that insecurity took a great toll on oil production in Nigeria between 1999 and 2008 Nigeria was producing at about $10 \%$ of its potentials of 3.4 million barrels of crude oil per day in 2007. Currently, the cost of petroleum production in Nigeria is higher than it was before 1999 because of the higher security expenditure necessary now (Otto and Ukpere, 2012).

Also, insecurity increases the unit cost of doing business in Nigeria. Apart from the fall in output and the increase in unit cost of production, many firms in different industries relocated away from the Niger Delta in particular. And some left the country completely. Example, include Michelin, Dunlop, among several others. An insecure environment impinges directly on development; it disenfranchises communities, contributes to poverty, distorts economies, creates instability and stunts political development. In Nigeria, apart from the millions of people who had been killed in course of one security breach or another, sources of livelihood were destroyed, families got disintegrated and social infrastructure were disrupted (Otto and Ukpere, 2012).

3. 1. Boko Haram Attacks in the Country

Boko Haram was a local radical Salafist group which transformed into a Salafi-jihadist terrorist organization (Chimezie, n.d.). On 6 July 2009, first clash was with security agencies in Bauchi State after an all-night attack on Dutsen-Tanshi Police, 39 members, two police, one soldier killed. 27 July 2009, first attack in Yobe State during an invasion of Potiskum Divisional Headquarters led to the death of three policemen, one Fire Service officer. On 29 July 2009, confrontation with security men at Mamudo Village, along Potiskum/Damaturu Road, Yobe, 33 Boko Haram men killed(Sani, 2011). On the same date in all-night battle with combine security operative at Railway Terminus, Maiduguri, Borno State, Boko Haram did not only kill but destroyed operational base of the combine security.

Since 2009, the Islamic sect Boko Haram has been blamed for many attacks in different parts of Nigeria including the Federal Capital Territory, Abuja. See Appendix for a timeline of attacks for which the sect has claimed responsibility.

4. Research Methodology

4.1 Area of Study

Nigeria is located between $4^{\circ} \mathrm{N}$ and $14^{\circ} \mathrm{N}$ of the equator. The western frontiers runs from $3^{\circ} \mathrm{E}$ and the eastern reaches nearly $15^{\circ} \mathrm{E}$ of the meridian (Margottini et al, 2013). Since it was impossible to conduct the research in the whole areas in Nigeria where BokoHarram attacks had happened. A few places were selected where severe impact and casualties were recorded after the attacks by Boko Haram. As such, the study purposely selected Kabba in Kogi State and Nyanya in Abuja.

Nyanya is a town, and a suburb of Abuja city in centralNigeria. It is a district of KaruLocal Government Area, Nasarawa State, and is among the towns that make up the Karu Urban Area, a conurbation of towns stretching to Nigeria's capital city, Abuja. Its neighbouring towns are Mararaba, Ado, Masaka, New Karu and Kurunduma and villages that grew, as a result of the rapid expansion of administrative and economic activities of Abuja, into neighbouring towns, coupled with the evacuation of tens of thousands of people from Abuja by the Federal Capital Territory administration (Wikipedia, 2013).

Kabba is a town in Kogi State in mid-west Nigeria. It lies near the Osse River, at the intersection of roads from Lokoja, Okene, Ogidi, Ado-Ekiti, and Egbe. The town is near Abuja. Kabba was the administrative headquarters of the Kabba province of the defunct Northern Region of Nigeria, which includes all of the current Kogi State. The town is the headquarters of the Kabba/Bunnu local government area of Kogistate.Kabba is a trade centre for coffee, cocoa, yams, cassava, maize, sorghum, shea nuts, peanuts (groundnuts), beans, cotton, and woven cloth produced by the Yoruba, Ebira, and other peoples of the surrounding area (Wikipedia, 2014).

4.2 Instrument Validity

To assess the validity, the instrument was piloted among 3 randomly selected household in each areas of the study. Responses, views, impatience and difficulties to complete the questionnaire were noted instantly by the researchers, this warranted restructuring the questionnaire by collapsing some instruments and resorting to two-option response format as against the Likert-type scale from 1 to 4 . As such the questionnaire was kept simple but still containing vital questions regarding the issue at hand. The final draft of the questionnaire was sent to a few colleagues who are knowledgeable in this field. It should also be noted that in-depth interview was conducted among the respondents in the study areas.

4.3 Sampling

60 questionnaires were administered randomly to households in Kabba inKogi state and also 60 households were randomly selected in Nyanya in Abuja where questionnaires were administered. A total of 100 questionnaires were retrieved out of 120 administered. This represented 83 percent retrieval rate. Table 2 in Appendix shows the questionnaire that was administered and the response. 
Data collected were subjected to statistical analysis using several statistical tables and analytical tools: descriptive statistics which use means and percentages for answering questions; inferential statistics such as one way analysis of variance classification; $\mathrm{Chi}^{2}$ test and test adopted in testing formulated hypothesis of the study at $5 \%$ level of significance.

5. Results and Discussion

The demographic result in Table 1 regarding the gender composition of respondents show $53 \%$ males while $47 \%$ of the respondents are females. $74 \%$ of the respondents are within the age of 21-30 years while $10 \%$ of the respondents are within the ages 1-20 years, also $10 \%$ of the respondents are within the ages $41-50$ and $6 \%$ of the respondents are within the ages of 31-40 years. The marital status of respondents shows $85 \%$ of the respondents as single while $4 \%$ are married. However, $10 \%$ of the respondents are widowed and $1 \%$ of the respondent appeared divorced. Majority of respondents as shown in the Table have tertiary education $(80 \%)$ while $18 \%$ of the respondents have primary/secondary education. Nonetheless, $2 \%$ of the respondents have other educational qualification. In terms of occupational distribution, the bulk of respondents are students (78\%);10\% of the respondents are civil servants; $11 \%$ of the respondents are business men/women; and $1 \%$ of the respondents is into trade. Still, from the bio data section of Table 1,79\% are respondents are Christians while $21 \%$ are Muslims. In section two of the questionnaire where research questions were ask, the information in Table 1 shows that most of the respondents $(89 \%)$ are aware that Boko Haram insurgency exists in Nigeria. Similarly, $85 \%$ said that they have been directly or indirectly affected by their insurgence.

About $78 \%$ of the respondents were of the opinion that Boko Haram insurgency has negatively affected national security in Nigeria while $22 \%$ of the respondents disagree that Boko Haram insurgency has negatively affected national security in Nigeria. Invariably, most of the respondents agree that Boko Haram insurgency has negatively affected national security in Nigeria. Moreover, 79 respondents representing $79 \%$ of the respondents agree that religious and political manipulations in Nigeria is an indication of Boko Haram insurgency while $21 \%$ of the respondents disagree. A large sum of respondents (86 in number or 86\%)agree that if religious and political manipulations is minimized in Nigeria, it will reduce Boko Haram insurgency.

On the subject of well-being, $87 \%$ of the respondents are of the perception that illiteracy, unemployment and poverty are responsible for Boko Haram insurgency in the country. Similarly, a large percentage of respondents $(90 \%)$ are of the opinion that corruption, bad governance and weak institutional framework also promote this insurgence.

On the issue of borders, $92 \%$ of the respondents agree that the long and porous borders, vast forest and deserts in Nigeria promotes Boko Haram insurgency while 8 respondents representing $8 \%$ of the respondents disagree on this on. A lot of the respondents (79\%) were highly of the opinion that if security is beefed up around the long and porous borders, vast forest and deserts in Nigeria, it will reduce Boko Haram activities. In a similar manner, majority of the respondents $(88 \%)$ disagree that the federal, state and local governments in Nigeria have done enough to reduce the sect's activities. The security operatives and security agencies have not done enough either. This is as expressed by $86 \%$ of respondents. A very high percentage of respondents $(99 \%)$ disagree that the fight against Boko Haram insurgency should be left for the security operatives and security agencies. if the general populace is educated on the need and importance of security and security consciousness at all times, it will reduce Boko Haram insurgency in Nigeria. This is the take of $98 \%$ of respondents.

5.1 Verification of Research Proposition

5.1.1 In-Depth Interview Report

The researchers interviewed ten respondents who were purposively chosen because of the questions they answered. These respondents include security operatives, security experts and journalists who were the key informants that gave detailed information about the subject under study. A summary report is made of the in-depth one-to-one interviews among the ten respondents to bring out the central messages of the interviews so as to avoid repetition as there are so many similarities in the answers given by the various respondents.

The respondents said that Boko Haram insurgency in Nigeria is as a result of different factors ranging from illiteracy, unemployment, poverty, corruption and bad governance, religious and political manipulations, the long and porous borders, vast forest and deserts. Commenting on illiteracy, the interview revealed that so many youths in all parts of Nigeria are still uneducated and this is causing serious problem as these uneducated youths engage in all forms of social vises. On unemployment, the interview revealed that graduated youths are parading the streets due to lack of jobs. On poverty, the respondents say that the level of poverty in the country is alarming owing to the fact that so many people cannot afford the basic necessities of life. On the issue of corruption and bad governance, the respondents say that in Nigeria, the federal, state and local government has failed in the provision of basic amenities such as infrastructure, health care delivery, education, and security despite the huge resources gotten from oil. On religious and political manipulation, the respondents say that Religious indoctrination and its influence have played 
great role in crisis in Nigeria and political manipulation has been in existence since independence and this has manifested itself in the area of access to power which guarantee access to resources and revenues. On the long and porous borders, vast forest and deserts, the respondents say that is has become worrisome in recent time as terrorist groups enter the country unchecked and use Nigeria's forests as their bases for recruitment and training camps for their new followers.

According to the respondents, the federal, state and local governments have not done enough to fight Boko Haram insurgency in Nigeria in the sense that security operatives are not provided with up to date weapons and security gadgets to tackle Boko Haram insurgents.

\subsubsection{Statistical Verification}

$\mathrm{H}_{0}$ states that there is no significant relationship between Boko Haram insurgency and national security in Nigeria. The Binomial test was used concerning the issue of security in Nigeria. As such the responses from the following questions were analyzed: Has Boko Haram insurgency negatively affected national security in Nigeria (NSEC)? Does the long and porous borders, vast forest and deserts in Nigeria promote Boko Haram insurgency(DLONG)?

\begin{tabular}{|c|c|c|c|c|}
\hline \multicolumn{5}{|c|}{ Hypothesis Test Summary } \\
\hline & Null Hypothesis & Test & Sig. & Decision \\
\hline 1 & $\begin{array}{l}\text { The categories defined by NSEC } \\
=\text { yes and =no occur with } \\
\text { probabilities } 0.5 \text { and } 0.5 \text {. }\end{array}$ & $\begin{array}{l}\mathrm{C}=\text { One-Sample } \\
\text { Binomial } \\
\text { Test }\end{array}$ & .000 & $\begin{array}{l}\text { Reject the } \\
\text { nuli } \\
\text { hypothesis. }\end{array}$ \\
\hline 2 & $\begin{array}{l}\text { The categories defined by DLOR } \\
==y e s \text { and }=\text { no occur with } \\
\text { probabilities } 0.5 \text { and } 0.5 \text {. }\end{array}$ & $\begin{array}{l}\text { NGOne-Sample } \\
\text { Binomial } \\
\text { Test }\end{array}$ & .000 & $\begin{array}{l}\text { Reject the } \\
\text { null } \\
\text { hypothesis. }\end{array}$ \\
\hline
\end{tabular}

Decide whether to reject $\mathrm{H}_{0}$. The $\mathrm{p}$ value in this case is .000 which is less than or equal to our $\alpha$ level of .05. Thus, we reject $\mathrm{H}_{0}$ that there is no significant relationship between Boko Haram insurgency and national security in Nigeria.

6. Conclusion and Policy Suggestions

The conclusion of this research is that terrorism is real in Nigeria especially with the activities of Boko Haram which includes bombing and killing of persons and targeting certain persons and places such the worship centre's, living homes, commercial buildings, telecommunication masts, government installations and infrastructure, kidnapping as well as depriving people of their legitimate entitlements. These terrorist activities are carried out by non-state actors and do not exclude politicians and government functionaries including security agency that ought to protect lives and properties. This paper suggests that:

The various levels of government should take governance as a serious business especially in the area of security (i.e., all government functionaries should be provided with sophisticated information gathering equipment that would enable them to detect terrorist activities early and nip them in the bud. Also, there is need to educate the general populace on the need and importance of security and security consciousness at all times) and provision of public goods such as improved infrastructure and the creation of the enabling environment needed for investment that would in turn creation opportunities for employments. The government should address the myriad of problems such as poverty, corruption, unemployment, drug trafficking and abuse etc., which are the likely precursors to violent reaction and the consequence insecurity.

Similarly, government should endeavor to make poor youth's part and parcel of development opportunities. More vocation that is youth centered should be introduced in Nigeria to enhance unskilled labor and boost their mental ability. Seminars/workshops on hand and personal skills should be organized for youths at the grass root level and there should be periodic evaluation of individuals so as to know their operational strength. This will help reduce social vices like political unrest, kidnappings, bombing and killing and so on, indulged by the youths in the society. In the same vein, government should build and renovate every dilapidated primary and secondary school and provide more education for the people at affordable rate, so that poor people can be educated. The acquisition of formal education enhances self-worth and develop human mental faculty.

For effective control of corruption, the society should insist on the development of the culture of relative openness, in contrast to the current bureaucratic system of secrecy. Leaders must ensure transparency and accountability in all levels of government and must be published. In that regard, the role of the press in public enlightenment campaign against corruption is very important in an attempt to eradicate corruption in Nigeria because this strategy can help to raise the peoples' awareness about the problem. 


\section{References}

Adebayo, A. (1986). Power in Politics. Ibadan: Spectrum Books.

Adesola, F. (2011). African Women and the Changing Notion of Security. (R. I. Ako-Nai (ed.) Gender and Power Relations in Nigeria. , Maryland \{USA\}: Lexington Publishers Inc. 220 - 235.

Bello, F. (n.d.) Public policy implication on national security. Retrieved fromhttp://www.google.com.ng.

Braithwaithe, T. (1988). "Foundations and Dynamics of National Security", Nigerian Journal of International Affairs .vol.12 No 3 pp107-127.

Chimezie, A. A. (n.d.). State of Emergency' as the best Policy Option for Boko Haram Terrorism.http://rieas.gr/images/alban.pdf Dyke, V.V. (1966).Security and Sovereignty in International Politics. New York:Appleton-Century-Crofts.

Edem, O.(n.d.).The Nigerian State and Sational http://www.nigerdeltacongress.com/narticles/nigerian_state_and_national_secu.htm Freedman, L (1998). "International Security: Changing Targets; Foreign Policy, 110(1),48-63.

Gompert, D. C., and Gordon, J. (2008). "War by Other Means: Building complete and balanced Capabilities for Counterinsurgency,"
http://www.rand.org/content/dam/rand/pubs/monographs/2008/RAND_MG595.2.Pdf. Imobighe, T.A. (1981). "African defense and Security: An Overview, "Nigerian Forum (April).

Kilcullen, D. (2006). "Counter-Insurgency Redux, in: Survival: The IISS Quarterly, Vol. 48, No.4, United Kingdom.

Liolio, S. E. (2013).Rethinking Counterinsurgency: A Case Study of Boko Haram in Nigeria. A thesis submitted to European Peace University (EPU), Private Universität, Stadtschlaining, Austria in partial fulfillment of the requirements for a Master of Arts Degree in Peace and Conflict Studies.

Margottini, C., Canuti, P. , and Sassa, K. (2013). Landslide Science and Practice: Volume 6: Risk Assessment. https://books.google.com.ng/books?isbn=3642313191. Morgenthau, H.(1948). Politics among nations. New York, Knopf.

Nweke, G.A. (1988). "Some Critical Remarks on the National Security Question”, Nigerian Journal of International Affairs. Vol. 12. pp. 1-7.

Odeselu, S. (2011). 'How Terror, Fear Affects Aviation Business' Guardian (Reported by Shadare W). Lagos.

Otto, G. (2008).'The Niger Delta Crisis and Its Impact on the Nigerian Economy'. Niger. J. Energy Environ. Econom., 4: 2. Awka.

Otto, G. and Ukpere, W. I. (2012).National security and development in Nigeria.African Journal of Business Management,.6 (23), 6765-6770.

Otubanjo, F. (1989). "Introduction: Phases and Changes in Nigeria's Foreign Policy”, in A. B. Akinyemiet. al. (eds.), Nigeria since Independence: The First 25 years, Volume X, International Relations, (Ibadan: Heinemann, ), p. 4.

Petraeus, Lt. Gen. David H.; and Amos, Lt. Gen. James F.(2006). "FM 3-24 Counterinsurgency," Marine Corps Warfighting Publication No. 3-33.5, Department of the Army, Washington, D.C.

Sani, S. (2011).Boko Haram: History, ideas and revolt(6).Vanguard. http://www.vanguardngr.com/2011/07/boko-haram-historyideas-and-revolt-6/

Sciencedaily (2015).Nationalsecurity.http://www.sciencedaily.com/articles/n/national_security.htm.

Thenationon(2014). Timeline of Boko Haram attackshttp://thenationonlineng.net/new/timeline-of-boko-haram-attacks/.

Thenet(2014). 2014: A timeline of Boko Haram attacks in Nigeria. http://thenet.ng/2014/06/2014-a-timeline-of-boko-haramattacks-in-nigeria/

Udama, R. A. (2013).Understanding Corruption in Nigeria and its Implications to National Security and Sustainable Development. OSR Journal Of Humanities and Social Science, 10(1), 60-73.

Wikipedia (2013).New Nyanya.http://en.wikipedia.org/wiki/New_Nyanya

Wikipedia (2014).Kabba.http://en.wikipedia.org/wiki/Kabba.

\section{Appendix}

Table 1: Timeline of Boko Haram Attacks in Nigeria From 2009 to 2014

\begin{tabular}{|c|c|c|c|}
\hline Date & Location Of Action & $\begin{array}{l}\text { Number } \\
\text { Of Deaths }\end{array}$ & $\begin{array}{l}\text { Number } \\
\text { Of Injured }\end{array}$ \\
\hline 6 July 2009 & Dutsen-Tanshi Police station, Bauchi State & 42 & $\mathrm{Xxx}$ \\
\hline 27 July 2009 & Potiskum Divisional Headquarters, Yobe State & 4 & $\mathrm{Xxx}$ \\
\hline 29 July 2009 & Mamudo Village, Yobe State & 33 & $\mathrm{Xxx}$ \\
\hline 29 July 2009 & Railway Terminus, Maiduguri, Borno State & several & $\mathrm{Xxx}$ \\
\hline 8 Sept. 2010 & Bauchi Central Prison, Bauchi State & $\mathrm{XXX}$ & $\mathrm{Xxx}$ \\
\hline 25 Dec. 2010 & Maiduguri & 6 & $\mathrm{Xxx}$ \\
\hline 30 Dec. 2010 & JOS & 32 & \\
\hline 31 Dec. 2010 & Abuja, Mogadishr military Barracks & 11 & 13 \\
\hline 9 Oct. 2011 & Maiduguri & $\mathrm{XXX}$ & $\mathrm{xxx}$ \\
\hline
\end{tabular}




\begin{tabular}{|c|c|c|c|}
\hline 8Aprail2011 & Suleja, INEC office & 16 & $\mathrm{Xxx}$ \\
\hline 16June 2011 & Abuja, Nigerian Police Headquarters & 8 & 44 \\
\hline 26June 2011 & Maiduguri & 25 & 12 \\
\hline 23 July 2011 & Maiduguri & 3 & several \\
\hline 30 July 2011 & Maiduguri & 5 & 10 \\
\hline 26Aug 2011 & Abuja, UN House & 26 & 116 \\
\hline 13Sep.2011 & Maiduguri & 4 & $\mathrm{Xxx}$ \\
\hline 4 Dec.2011 & Azare,Katagum L.G.A Bauchi State & 3 & $\mathrm{xxx}$ \\
\hline 7 Dec.2011 & Kaduna & 7 & $\mathrm{Xxx}$ \\
\hline 13 Dec.2011 & Maiduguri & 10 & 30 \\
\hline 22 Dec.2011 & Maiduguri \&Damaturu & 4 & $\mathrm{xxx}$ \\
\hline 25 Dec 2011 & Jos, Suleja\&Yobe & 43 & $\mathrm{xxx}$ \\
\hline 28 Dec 2011 & Sapele, Delta, Hausa Quarters & $\mathrm{xxx}$ & 7 \\
\hline 30 Dec 2011 & Gombe, Hotel & $\mathrm{XXX}$ & 15 \\
\hline $5 / 6$ Jan.2012 & Gombe\& Adamawa State & 28 & $\mathrm{Xxx}$ \\
\hline 7 Jan. 2012 & Adamawa & 17 & 12 \\
\hline 20 Jan. 2012 & Kano & 162 & $\mathrm{Xxx}$ \\
\hline 22 Jan.2012 & Bauchi & 11 & $\mathrm{Xxx}$ \\
\hline 3 Feb. 2012 & Kogi State, Police Station & 4 & $\mathrm{Xxx}$ \\
\hline 11March2012 & Jos & 10 & $\mathrm{xxx}$ \\
\hline 24March2012 & Kano & 2 & $\mathrm{Xxx}$ \\
\hline 8 April 2012 & Jos & 20 & $\mathrm{Xxx}$ \\
\hline 8 April 2012 & Kaduna & 40 & $\mathrm{Xxx}$ \\
\hline 25 April 2012 & Maiduguri, Police Headquarters & 7 & $\mathrm{xxx}$ \\
\hline 26 April 2012 & Abuja, Kaduna & 6 & $\mathrm{xxx}$ \\
\hline 29April 2012 & Bayero University, Kano & 16 & $\mathrm{Xxx}$ \\
\hline 30April 2012 & Taraba & 11 & $\mathrm{Xxx}$ \\
\hline 3 June 2012 & Bauchi & 12 & $\mathrm{Xxx}$ \\
\hline 8 June 2012 & Maiduguri & $\mathrm{xxx}$ & $\mathrm{Xxx}$ \\
\hline 10 June 2012 & Jos & 8 & $\mathrm{Xxx}$ \\
\hline 17 June 2012 & Kaduna \& Zaria & 40 & $\mathrm{Xxx}$ \\
\hline 22 June 2012 & Abuja & $\mathrm{XXX}$ & $\mathrm{Xxx}$ \\
\hline 13 July 2012 & Maiduguri & 5 & $\mathrm{Xxx}$ \\
\hline 30 July 2012 & Zaria \& Kaduna & 5 & $\mathrm{Xxx}$ \\
\hline 14August2014 & Kaduna & 4 & $\mathrm{Xxx}$ \\
\hline 23 Sept. 2012 & Bauchi & 2 & 46 \\
\hline 5 Oct. 2012 & Maiduguri & 1 & 11 \\
\hline 6 Oct. 2012 & Taraba & $\mathrm{xxx}$ & 8 \\
\hline 8 Oct. 2012 & Maiduguri & 35 & $\mathrm{Xxx}$ \\
\hline 28 Oct. 2012 & Kaduna & 8 & 100 \\
\hline 7 May 2013 & Bama & 55 & $\mathrm{Xxx}$ \\
\hline 6 July 2013 & Yobe State & 42 & $\mathrm{Xxx}$ \\
\hline 12 Feb. 2014 & Konduga & 39 & $\mathrm{Xxx}$ \\
\hline 12 Feb. 2014 & Wajirko & 4 & 6 \\
\hline 16 Feb 2014 & Borno & 90 & $\mathrm{Xxx}$ \\
\hline $19 \mathrm{Feb} 2014$ & Bama & 60 & $\mathrm{Xxx}$ \\
\hline 25 Feb 2014 & BuniYadi & 59 & $\mathrm{Xxx}$ \\
\hline 1 March 2014 & Maiduguri & 51 & $\mathrm{Xxx}$ \\
\hline 1 March 2014 & Mainok & 39 & $\mathrm{Xxx}$ \\
\hline 10 April 2014 & Kala Balge & 60 & $\overline{x x x}$ \\
\hline 10 April 2014 & Dikwa & 8 & $\mathrm{Xxx}$ \\
\hline 14 April 2014 & Nyanya, Abuja & 88 & 125 \\
\hline
\end{tabular}




\begin{tabular}{llll}
\hline 1 May 2014 & Nyanya, Abuja & 19 & 60 \\
\hline 5 May 2014 & GamboroNgala & 300 & $\mathrm{Xxx}$ \\
\hline 18 May 2014 & Kano & 4 & $\mathrm{Xxx}$ \\
\hline 20 May 2014 & Jos & 118 & 56 \\
\hline 21 May 2014 & Chikongudu & 25 & $\mathrm{Xxx}$ \\
\hline 25 May 2014 & Yobe\&Borno State & 48 & $\mathrm{Xxx}$ \\
\hline 27 May 2014 & Borno State & 48 & $\mathrm{Xxx}$ \\
\hline 31 May 2014 & Kala/Balge & 40 & $\mathrm{Xxx}$ \\
\hline
\end{tabular}

Source: Thenationon(2014), Thenet(2014).

Table 2: Questionnaire Administered and the Response

\begin{tabular}{|c|c|c|}
\hline \multicolumn{3}{|l|}{ Part One: Bio Data About Respondent } \\
\hline Sex & Frequency & Percentage \\
\hline Male & 53 & $53 \%$ \\
\hline Female & 47 & $47 \%$ \\
\hline Total & 100 & $100 \%$ \\
\hline Age & Frequency & Percentage \\
\hline $1-20$ & 10 & $10 \%$ \\
\hline $21-30$ & 74 & $74 \%$ \\
\hline $31-40$ & 6 & $6 \%$ \\
\hline $41-50$ & 10 & $10 \%$ \\
\hline 51-Above & - & - \\
\hline Total & 100 & $100 \%$ \\
\hline Marital Status & Frequency & Percentage \\
\hline Single & 85 & $85 \%$ \\
\hline Married & 4 & $4 \%$ \\
\hline Divorced & 1 & $1 \%$ \\
\hline Widow & 10 & $10 \%$ \\
\hline Total & 100 & $100 \%$ \\
\hline Educational Qualification & Frequency & Percentages \\
\hline Primary/Secondary & 18 & $18 \%$ \\
\hline Tertiary & 80 & $80 \%$ \\
\hline Others & 2 & $2 \%$ \\
\hline Total & 100 & $100 \%$ \\
\hline Occupational Status & Frequency & Percentages \\
\hline Civil Servants & 10 & $10 \%$ \\
\hline Business Men/Women & 11 & $11 \%$ \\
\hline Students & 78 & $78 \%$ \\
\hline Traders & 1 & $1 \%$ \\
\hline Total & 100 & $100 \%$ \\
\hline Religion & Frequency & Percentage \\
\hline Islam & 21 & $21 \%$ \\
\hline Christianity & 79 & $79 \%$ \\
\hline Traditional Worshippers & - & - \\
\hline Total & 100 & $100 \%$ \\
\hline \multicolumn{3}{|l|}{ Part Two: Research Questions } \\
\hline Does Insurgence Exist In Nigeria & Frequency & Percentage \\
\hline Yes & 89 & $89 \%$ \\
\hline No & 11 & $11 \%$ \\
\hline Total & 100 & $100 \%$ \\
\hline Has Boko Haram Insurgency Affected You Directly Or & Frequency & Percentage \\
\hline
\end{tabular}




\begin{tabular}{|c|c|c|}
\hline Indirectly & & \\
\hline Yes & 85 & $85 \%$ \\
\hline No & 15 & $15 \%$ \\
\hline Total & 100 & $100 \%$ \\
\hline $\begin{array}{l}\text { Has Boko Haram Insurgency Negatively Affected } \\
\text { National Security In Nigeria }\end{array}$ & Frequency & Percentage \\
\hline Yes & 78 & $78 \%$ \\
\hline No & 22 & $22 \%$ \\
\hline Total & 100 & $100 \%$ \\
\hline $\begin{array}{l}\text { Is Illiteracy, Unemployment And Poverty Responsible } \\
\text { For Boko Haram Insurgency }\end{array}$ & Frequency & Percentage \\
\hline Yes & 87 & $87 \%$ \\
\hline No & 13 & $13 \%$ \\
\hline Total & 100 & $100 \%$ \\
\hline $\begin{array}{l}\text { Is Corruption,Bad Governance } \\
\text { And Weak Institutional Framwork The Cause Of Boko } \\
\text { Haram Insurgency }\end{array}$ & Frequency & Percentage \\
\hline Yes & 90 & $90 \%$ \\
\hline No & 10 & $10 \%$ \\
\hline Total & 100 & $100 \%$ \\
\hline $\begin{array}{l}\text { Is Religious And Political Manipulations An Indication } \\
\text { Of Boko Haram Insurgency }\end{array}$ & Friquency & Percentage \\
\hline Yes & 79 & $79 \%$ \\
\hline No & 21 & $21 \%$ \\
\hline Total & 100 & $100 \%$ \\
\hline $\begin{array}{l}\text { If Religious And Political Manipulations Is } \\
\text { Minimized,It Will Reduce Boko Haram Insurgency }\end{array}$ & Frequency & Percentage \\
\hline Yes & 86 & $86 \%$ \\
\hline No & 14 & $14 \%$ \\
\hline Total & 100 & $100 \%$ \\
\hline $\begin{array}{l}\text { Does The Long And Porous Borders, Vast Forest And } \\
\text { Deserts In Nigeria Promote Boko Haram Insurgency }\end{array}$ & Frequency & Percentage \\
\hline Yes & 92 & $92 \%$ \\
\hline No & 8 & $8 \%$ \\
\hline Total & 100 & $100 \%$ \\
\hline $\begin{array}{l}\text { If Security Is Beefed Up Around The Borders And } \\
\text { Deserts, Will It Reduce Boko Haram Insurgency }\end{array}$ & Frequency & Percentage \\
\hline Yes & 79 & $79 \%$ \\
\hline No & 21 & $21 \%$ \\
\hline Total & 100 & $100 \%$ \\
\hline $\begin{array}{l}\text { Has The Federal, State And Local Government, Done } \\
\text { Enough To Reduce Boko Haram Insurgency }\end{array}$ & Frequency & Percentage \\
\hline Yes & 12 & $12 \%$ \\
\hline No & 88 & $88 \%$ \\
\hline Total & 100 & $100 \%$ \\
\hline $\begin{array}{l}\text { Has Security Operatives And Security Agencies Done } \\
\text { Enough To Reduce Boko Haram Insurgency }\end{array}$ & Frequency & Percentage \\
\hline Yes & 14 & $14 \%$ \\
\hline No & 86 & $86 \%$ \\
\hline Total & 100 & $100 \%$ \\
\hline $\begin{array}{l}\text { Should The Fight Against Boko Haram Insurgency Be } \\
\text { Left For The Security Agencies And Security } \\
\text { Operatives Alone }\end{array}$ & Frequency & Percentage \\
\hline
\end{tabular}




\begin{tabular}{lll}
\hline Yes & 1 & $1 \%$ \\
\hline No & 99 & $99 \%$ \\
\hline Total & 100 & $100 \%$ \\
\hline If The General Populace Are Educated On The Need & Frequency & Percentage \\
And Importance Of Security And Security & & \\
Consciousness At All Times, Will Reduce Boko Haram & & \\
Insurgency & & \\
\hline Yes & 98 & $98 \%$ \\
\hline No & 2 & $2 \%$ \\
\hline Total & 100 & $100 \%$ \\
\hline Source: & & \\
\hline
\end{tabular}

Source: Field survey.

\section{Copyrights}

Copyright for this article is retained by the author(s), with first publication rights granted to the journal. This is an open-access article distributed under the terms and conditions of the Creative Commons Attribution license (http://creativecommons.org/licenses/by/4.0/) 